\title{
Infected infarcts of the testis: A study of 18 cases preceded by pyogenic epididymoorchitis
}

\author{
D. O'B. HOURIHANE
}

From the Central Histopathology Laboratory of the Federated Dublin Hospitals School of Pathology, Trinity College, Dublin

SYNOPSIS Eighteen cases of infected infarcts of the testis are presented, and evidence is put forward that these result from venous occlusions in the epididymis and cord. The venous lesions probably result from thrombosis during the course of an attack of epididymoorchitis.

Granulomatous orchitis was present in some part of half of the orchidectomy specimens, $\vec{\theta}$ and the clinical histories, bacteriological findings, and histological data all suggest that this 0 form of inflammation results from pyogenic infection of the testicle. What the factor is which determines whether the inflammation is granulomatous or not is unknown.

Apart from torsion and occasional involvement in polyarteritis nodosa testicular infarction is rare, and the receipt of several specimens stimulated interest in the lesion.

Between January 1964 and December 1969 we have received 18 testes with infarcts (excluding cases of torsion) and this paper presents the findings from their study.

The ages of the patients ranged from 26 years to 74 years, the majority being between 30 and 65 years (Table I). Most of the patients had a history of urinary tract disease, mainly of attacks of cystitis, often with haematuria. The common history was of 'cystitis' for seven to 10 days, then of the development of testicular pain and swelling usually diagnosed as epididymoorchitis (Tables I and II). Conservative treatment for three to seven weeks failed to lead to resolution and many developed a fluctuant mass in the testis. In six patients a scrotal sinus developed and in six others its imminence dictated immediate orchidectomy (Tables I and II).

In most of the patients $E$. coli was cultured from the urine, and in all cases in which culture Received for publication 12 February 1970.

\begin{tabular}{|c|c|c|c|c|c|c|}
\hline \multirow[t]{2}{*}{$\begin{array}{l}\text { Case } \\
\text { No. }\end{array}$} & \multirow[t]{2}{*}{$\begin{array}{l}\text { Age } \\
(y r)\end{array}$} & \multirow{2}{*}{$\begin{array}{l}\text { Clinical } \\
\text { Epididymo- } \\
\text { orchitis }\end{array}$} & \multirow{2}{*}{$\begin{array}{l}\text { Haema- } \\
\text { turia }\end{array}$} & \multicolumn{2}{|c|}{$\begin{array}{l}\text { E. coli Cul- } \\
\text { tured from }\end{array}$} & \multirow[t]{2}{*}{$\begin{array}{l}\text { Previous } \\
\text { Surgery }\end{array}$} \\
\hline & & & & Urine & Testis & \\
\hline 1 & 55 & + & & $0^{1}$ & + & \\
\hline 2 & 43 & \pm & & + & 0 & 음 \\
\hline 3 & 60 & & & 0 & + & \\
\hline 4 & 48 & - & & & + & \multirow{2}{*}{$\begin{array}{l}\text { Hernial repair } \\
\text { Transurethral } \\
\text { resection of } \\
\text { prostate }+ \\
\text { hernial repair }\end{array}$} \\
\hline 5 & 69 & - & & \multicolumn{2}{|c|}{ Ps.pyo. 0} & \\
\hline 6 & 30 & + & + & - & + & N \\
\hline 7 & 56 & + & + & 0 & + & N \\
\hline 8 & 70 & - & & - & + & a \\
\hline 9 & 30 & + & + & + & & 0 \\
\hline 10 & 36 & + & & - & Proteus & $\mathbf{s}$ \\
\hline 11 & 26 & - & + & 0 & 0 & 음 \\
\hline 12 & 67 & - & & - & $\mathbf{0}$ & Hernial repair \\
\hline 13 & 71 & + & + & + & + & \\
\hline 14 & 48 & + & & - & + & \\
\hline 15 & 42 & + & & - & + & \\
\hline 16 & 45 & + & & + & 0 & $\bar{c}$ \\
\hline 17 & 57 & + & + & 0 & + & \\
\hline 18 & 74 & + & + & + & + & $\begin{array}{l}\text { Hernial repair } \\
\text { and retro- } \\
\text { pubic prostat- }\end{array}$ \\
\hline & & & & & & ectomy \\
\hline
\end{tabular}




\begin{tabular}{|c|c|c|c|}
\hline $\begin{array}{l}\text { Case } \\
\text { No. }\end{array}$ & $\begin{array}{l}\text { Testicular } \\
\text { Swelling (no. of } \\
\text { days before } \\
\text { operation) }\end{array}$ & $\begin{array}{l}\text { Scrotal Skin } \\
\text { Involved }\end{array}$ & $\begin{array}{l}\text { Histology of } \\
\text { Surviving Testis }\end{array}$ \\
\hline 1 & 50 & + & $\mathbf{F}$ \\
\hline 2 & 44 & & 0 \\
\hline 3 & 38 & & 0 \\
\hline 4 & 21 & & $\mathbf{F}$ \\
\hline 5 & $?$ & + & $\mathbf{F}$ \\
\hline 6 & 31 & + & $\mathbf{F}$ \\
\hline 7 & 51 & - & G \\
\hline 8 & 26 & - & $\mathbf{G}$ \\
\hline 9 & 35 & + & $\mathbf{F}$ \\
\hline 10 & 40 & + & 0 \\
\hline 11 & $?$ & + & $\mathbf{M}$ \\
\hline 12 & $?$ & + & $\mathbf{F}$ \\
\hline 1) & 64 & - & $\mathbf{M}$ \\
\hline 14 & 36 & \pm & $\mathbf{F}$ \\
\hline 15 & 42 & + & $\mathbf{M}$ \\
\hline 16 & 28 & \pm & $\mathbf{M}$ \\
\hline 17 & 42 & + & $\mathbf{G}$ \\
\hline 18 & $?$ & + & $\mathbf{F}$ \\
\hline
\end{tabular}

Table II Length of history, involvement of skin, and histology of surviving testes in 18 patients

0 = no recognizable viable testis.

$F=$ fibrotic tubules.

$\mathbf{G}=$ granulomatous tubules.

$\mathbf{M}=$ both fibrotic and granulomatous tubules.

of the testicular tissue was performed $E$. coli was grown. Four patients had had a hernial repair (three ipsilateral and one contralateral) and two patients had had a recent prostatectomy.

\section{Pathology}

The specimens were extraordinarily similar so that the naked eye appearances could almost lead one to predict the history of the patient.

There were two types. In the first and most common (12 cases) the testis was of normal size or slightly enlarged. The cord was thickened by greywhite fibrous tissue in which were scattered yellow-brown foci, and the cut surface of the testis was more or less replaced by a yellow-green suppurative mass in which tubules could still be identified (Fig. 1). The surviving testis (if any) was represented by a peripheral rim of pale brown soft tissue. The tunica was usually grossly thickened, and skin was attached to it and communicated with the underlying abscess in seven cases (Figs. 1 and 2).

In those cases with generalized enlargement the testis was replaced by rubbery, firm, creamyyellow lobulated tissue, from which the infarct could be clearly distinguished (Fig. 3). The cord was thickened as in the first group with yellow foci scattered in dense white fibrous tissue.

\section{Histology}

All sections were stained with haematoxylin and

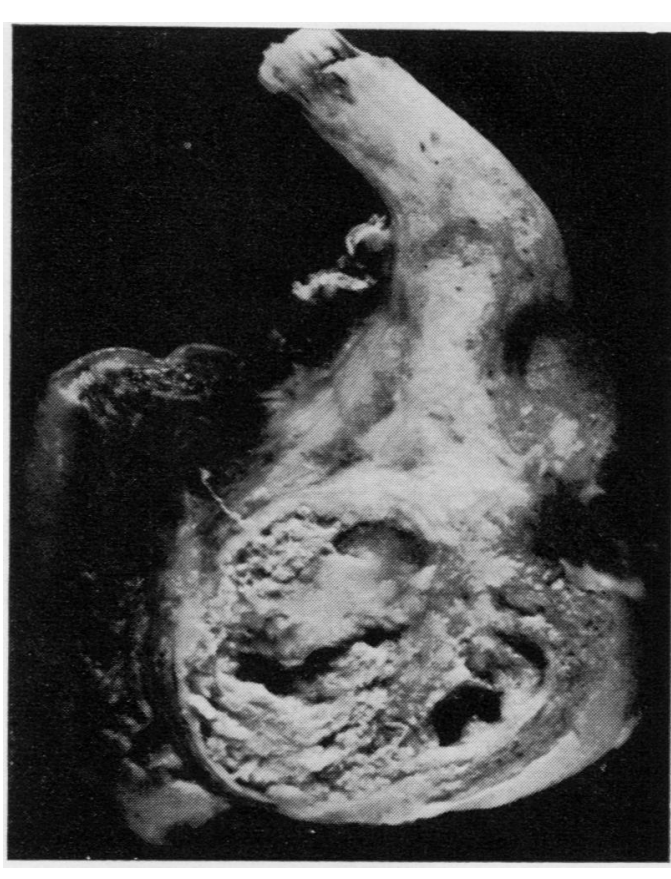

Fig. 1 Sagittal slice of orchidectomy specimen shows necrosis of most of the testis. A thin rim of surviving parenchyma is seen at the bottom right-hand corner of the photograph.

The fibrous thickening of the cord is well shown, and attached scrotal skin is indistinctly visible at the left-hand side of the specimen.

Case 11: histology of epididymis is shown in Figures 9 and 10.

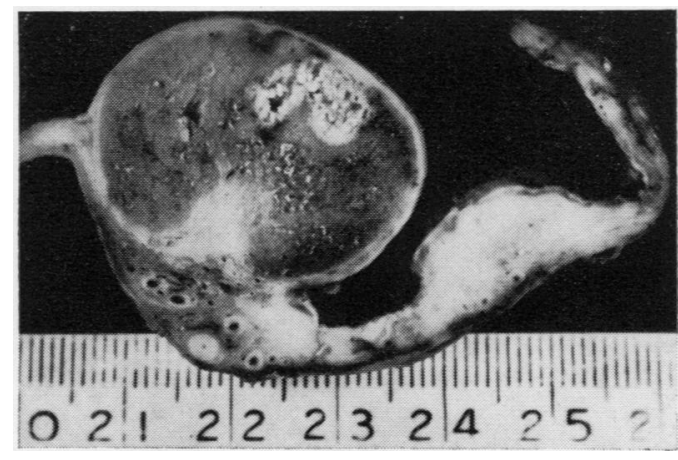

Fig. 2 Horizontal slice of orchidectomy specimen shows a small sharply demarcated zone of necrosis in the anterior part of the testis. Note the gross thickening of the tunica. The viable testis showed fibrotic seminiferous tubules.

Case 12: histology of border of necrotic zone is shown in Figure 4. 
Fig. 3.
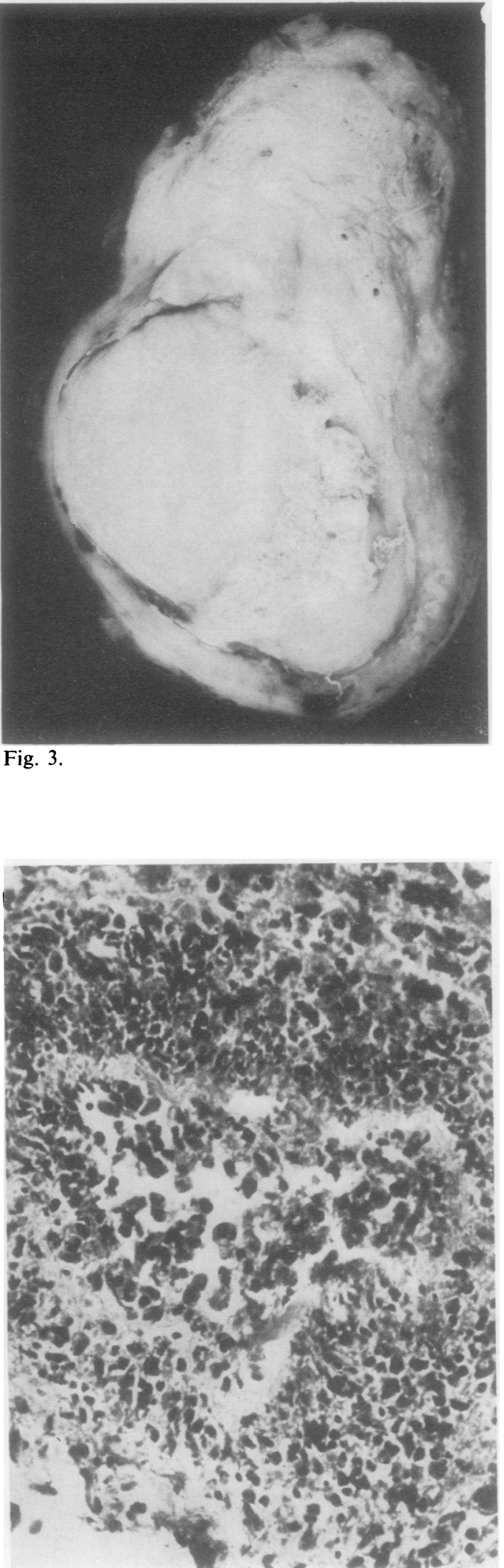

Fig. 5.

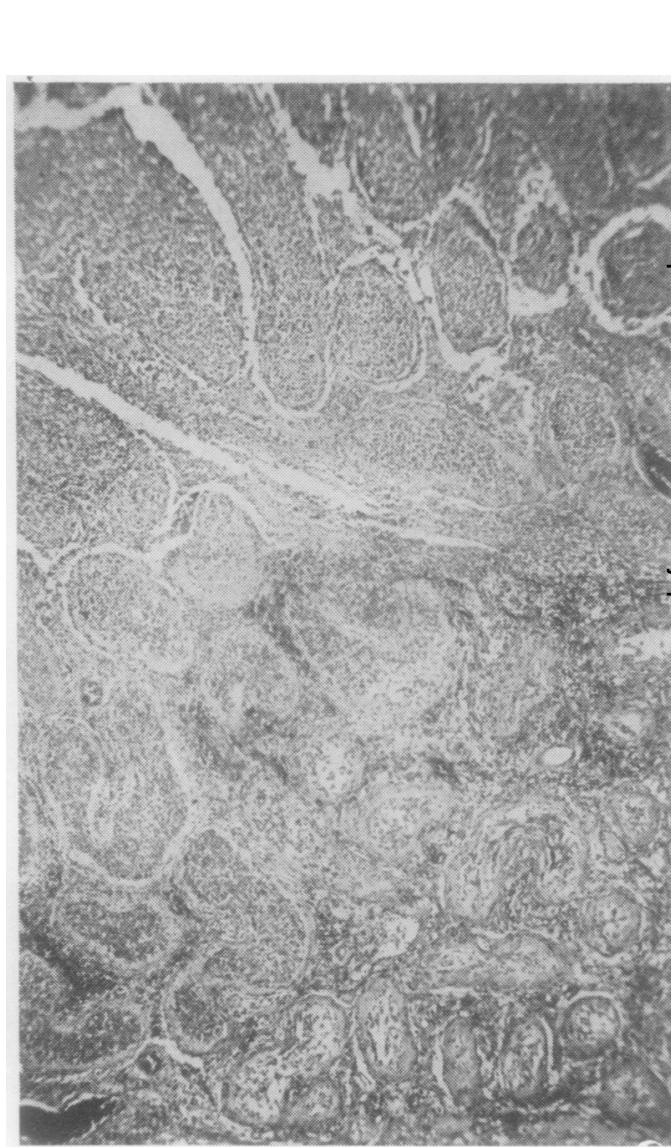

Fig. 4.

Fig. 3 Testis enlarged by firm, pale tissue, with a distinct zone of necrosis in the lower part of the specimen? Cord grossly thickened.

Case 13: history of testicular swelling for 64 days. Histology in Figs. 6 and 7 shows a mixture of granulomatous and fibrotic tubules.

Fig. 4 Area of necrosis of tubules at the top of the photograph, with fibrotic, viable tubules at the foot. A thin haemorrhagic zone between the two areas runs $\tilde{O}$ diagonally across the photograph. Specimen is shown in Figure 2.

Case 12: haematoxylin and eosin $\times 54$.

Fig. 5 Outline of a seminiferous tubule surrounded by inflammatory infiltrate.

Case 17: history 42 days. $H$ and $E \times 750$. 


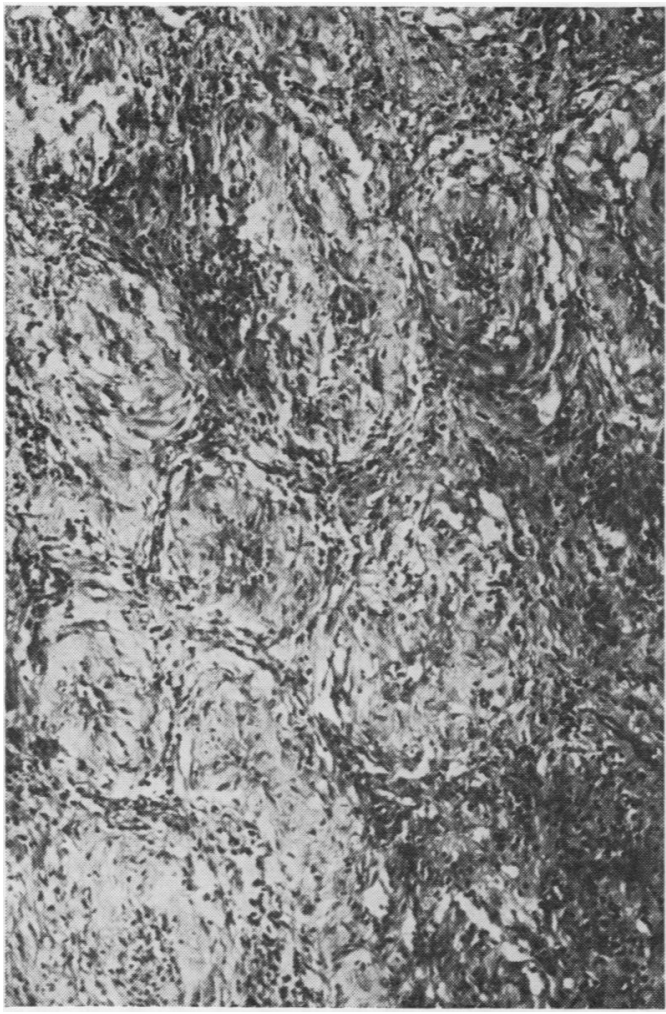

Fig. 6.

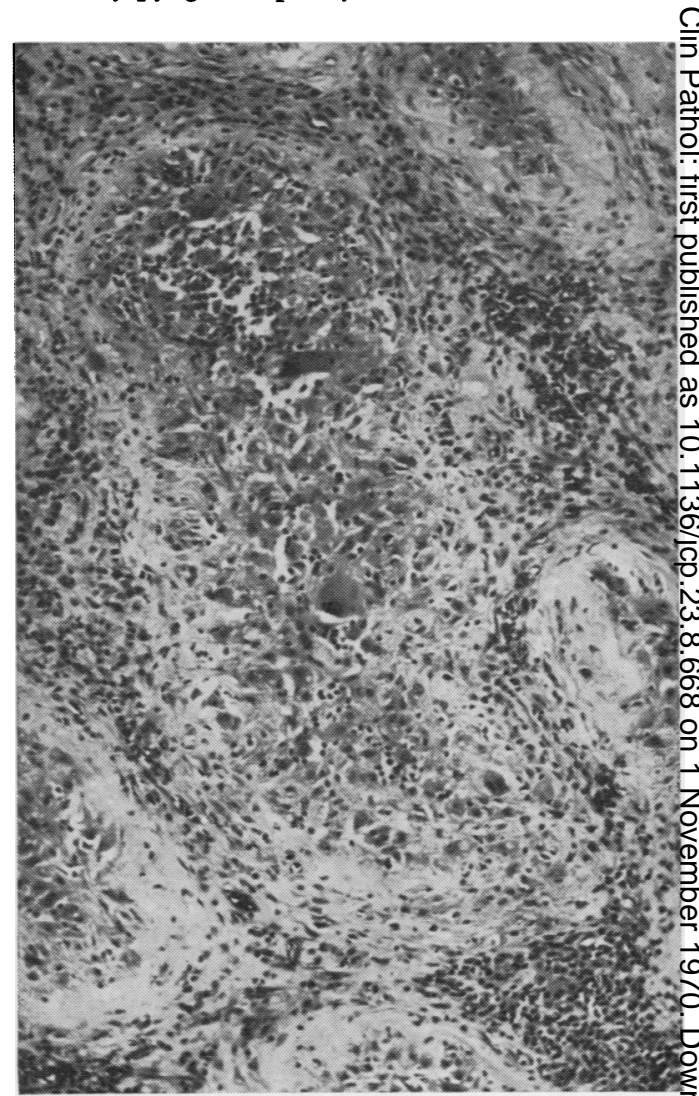

Fig. 8.

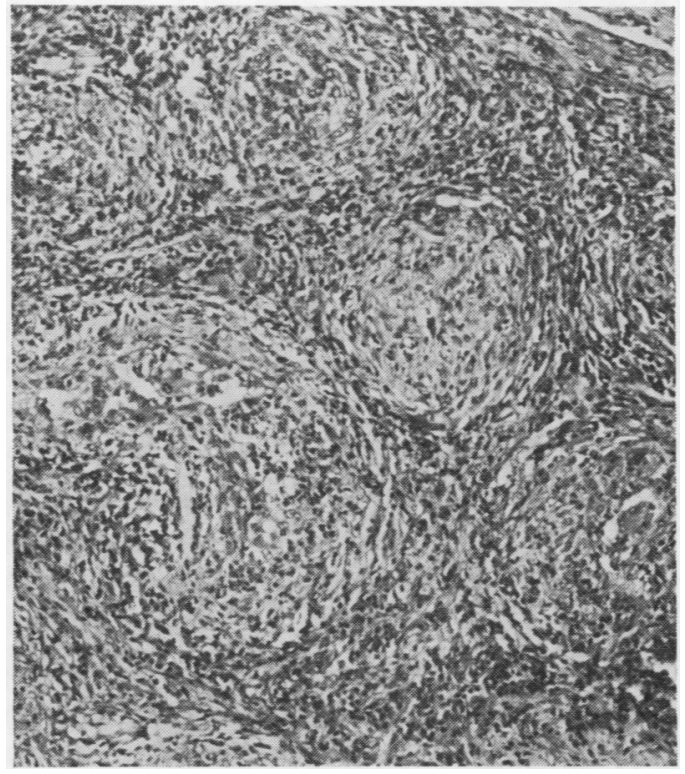

Fig. 7.
Fig. 6 Fibrotic seminiferous tubules, lined by a single layer of mononuclear cells. These cells usually contained lipid, and are probably modified Sertoli cells. Same case as in Figures 3 and 7.

Case 13: history 64 days. $H$ and $E \times 180$.

Fig. 7 Intratubular granulomata, with intense interstitial inflammation.

Case 13: history 64 days. $H$ and $E \times 180$.

Fig. 8 A single seminiferous tubule lies vertically in $N$ the photograph, and is filled by large, pink, mononuclean cells. Multinucleated giant cells can be seen, and polymorphs are identifiable within the upper and lower ends of the tubule.

Case 17: history 42 days. $H$ and $E \times 180$.

Fig. 9 Interstitial histiocytic and lymphocytic infiltrate between epididymal tubules. Specimen is shown in Figure 1.

Case 11: $H$ and $E \times 180$.

Fig. 10 Intratubular exudate in epididymis. Note peritubular histiocytes.

Case 11: $H$ and $E \times 300$.

○ W 


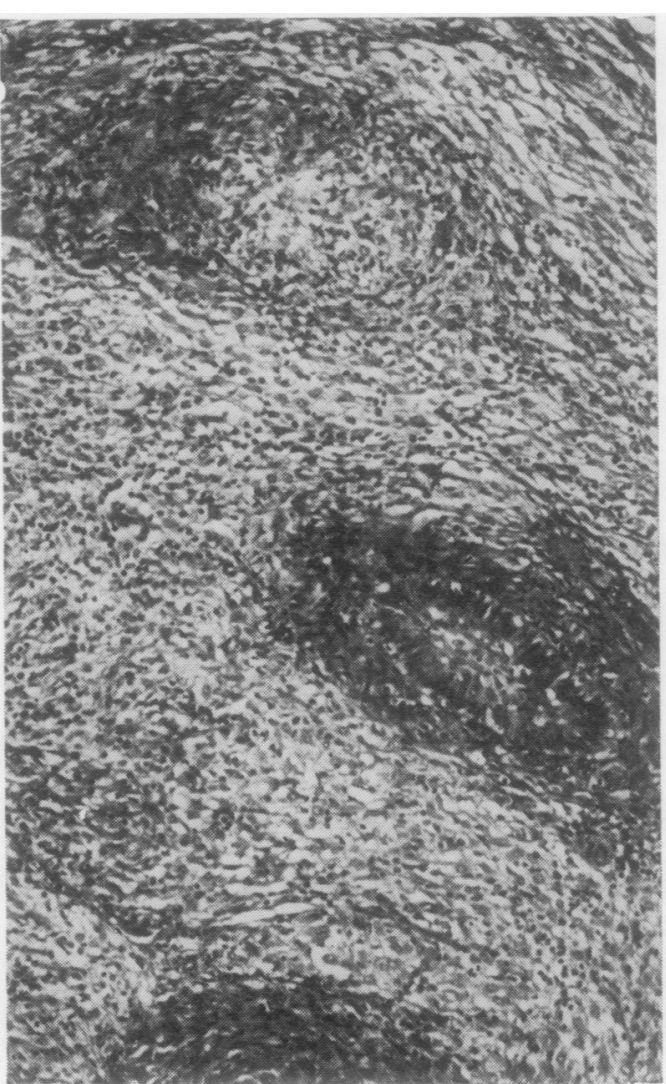

Fig. 9.

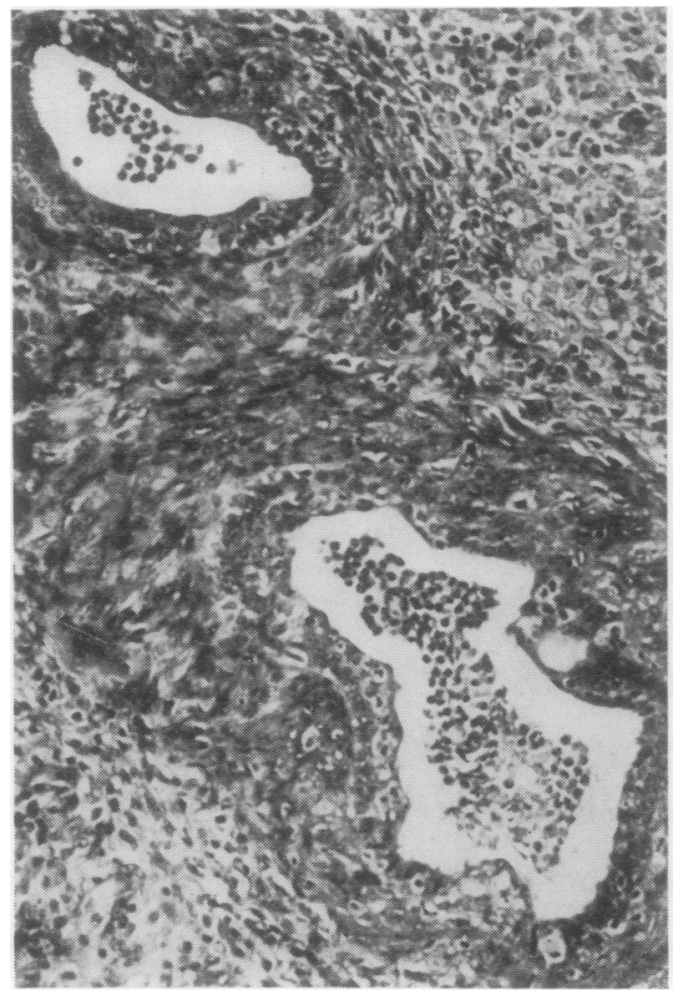

Fig. 10. eosin, and all suspected vascular lesions were $\frac{\rho}{\overline{\bar{J}}}$ stained with Sheridan's method for elastic tissue. Dै Ziehl-Neelsen stains were performed on all ${ }_{0}$ granulomatous specimens. Brown pigment was $\frac{\text {. }}{2}$ stained with Perls's acid ferrocyanide method for $\overrightarrow{\vec{F}}$ haemosiderin, and with a long Ziehl-Neelsen? method for acid fastness. Frozen sections were stained for fat with oil red $\mathbf{O}$.

There was again a general resemblance between $\frac{\frac{T}{\vec{D}}}{8}$ the cases. No normal tubules or spermatozoa were identified in any specimen. In the testes of ${ }^{\infty}$ normal size the central necrotic zone showed a. mixture of infarction and suppuration (Figs. $4 \overrightarrow{\vec{H}}$ and 5) with polymorphs infiltrating necrotic ${ }_{\sigma}$ tubules, the outlines of which were still detectable (Fig. 5). Occasional haematoidin crystals were seen within the necrotic zones. A thin haemor- $-\infty$ rhagic border was present separating necroticio from viable tubules in some specimens (Fig. 4). The surviving peripheral area of testis showedo fibrotic tubules lined by Sertoli cells with occa- sional intratubular granulomatous zones (Fig. 6). $Z$

The larger testes were swollen by a granulo-matous intratubular reaction (granulomatous $\overline{3}$ orchitis, Figs. 7 and 8) with some fibrotic tubules@ in peripheral areas, but their necrotic zones were $\vec{\oplus}$ similar to those of the smaller testes.

Inflammation of the epididymis was present in. all cases. In many it was purely histiocytic whileo in others polymorphs were scattered in the histio-s cytic infiltrate and in the neighbouring fibrouso tissue. Exudate was always present both betweeno and within tubules (Figs. 9 and 10), althougho tubules were difficult to identify in some speci- $\overrightarrow{0}$ mens. The cord was commonly thickened by 3 fibrous tissue and scattered foci of lymphocytes? and histiocytes, while dilated lymphatics and sclerosed blood vessels were prominent.

A feature of 17 of the specimens was the presence of totally occluded veins in the epidi-3. dymis and cord (Fig. 11). Many of these contained haemosiderin granules and were heavily infiltrated with plasma cells and lymphocytes (Figo 12) while others were recanalized and showed immature collagen between the new channelso (Figs. 13 and 14). Endophlebitis (Fig. 15) and extreme narrowing of veins by intimal collageno were common findings (Fig. 16).

Frozen sections were available from nine specimens, including sections of epididymis andb testis in each case. Lipid was demonstrated by oif red $O$. Large aggregates of lipid-laden histiocyte were present in the epididymis but the venouss? occlusions were uniformly negative for fat. Manyo of the seminiferous tubules were lined by lipid. containing cells. In general, those lined by a single layer contained more lipid than those filled byD granuloma. Interstitial lipid was focally present but not prominent.

Foci of intracellular brown pigment were foun£ in the interstitium of the epididymis and in occas. sional seminiferous tubules; most of this pigmenf 


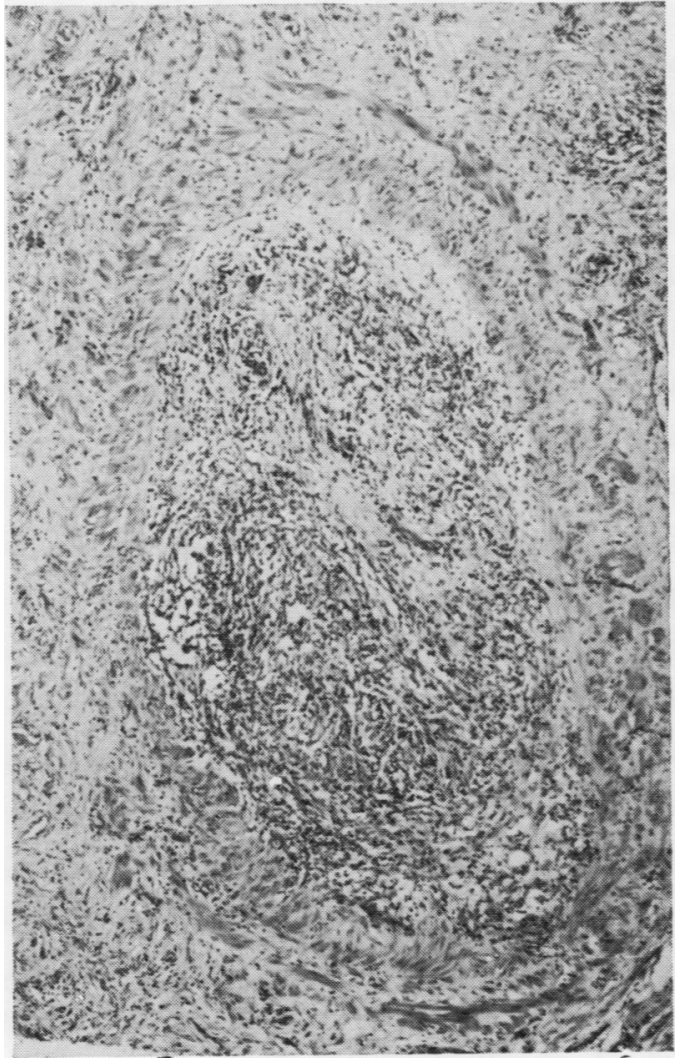

Fig. 11 Totally occluded vein in spermatic cord. Heavy cellular infiltrate occupies lumen.

Case 7: history 51 days. $H$ and $E \times 750$.

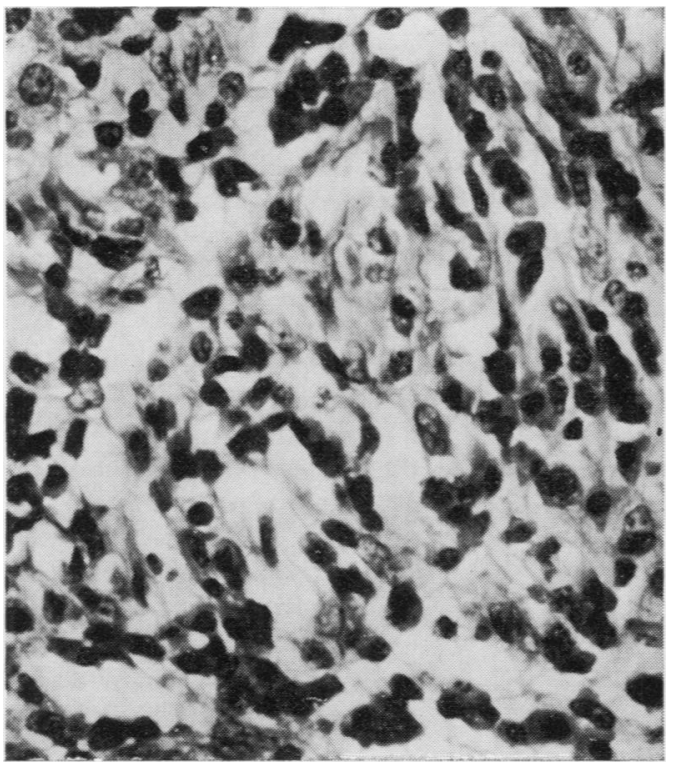

Fig. 12 Higher magnification of intravascular tissue in Figure 11. Largely lymphoid cells with some histiocytes and intercellular connective tissue.

Case 7: history 51 days. $H$ and $E \times 1,200$.

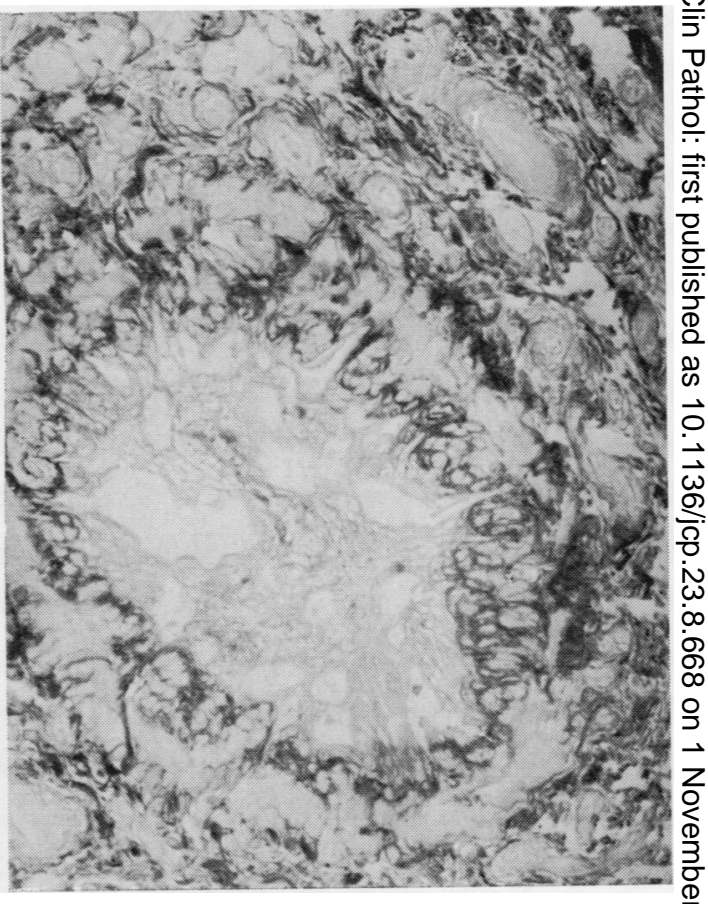

Fig. 13 Multiple channels of recanalized vein.

Case 17: history 42 days. Sheridan's elastic stain, counterstained with van Gieson stain $\times 180$.

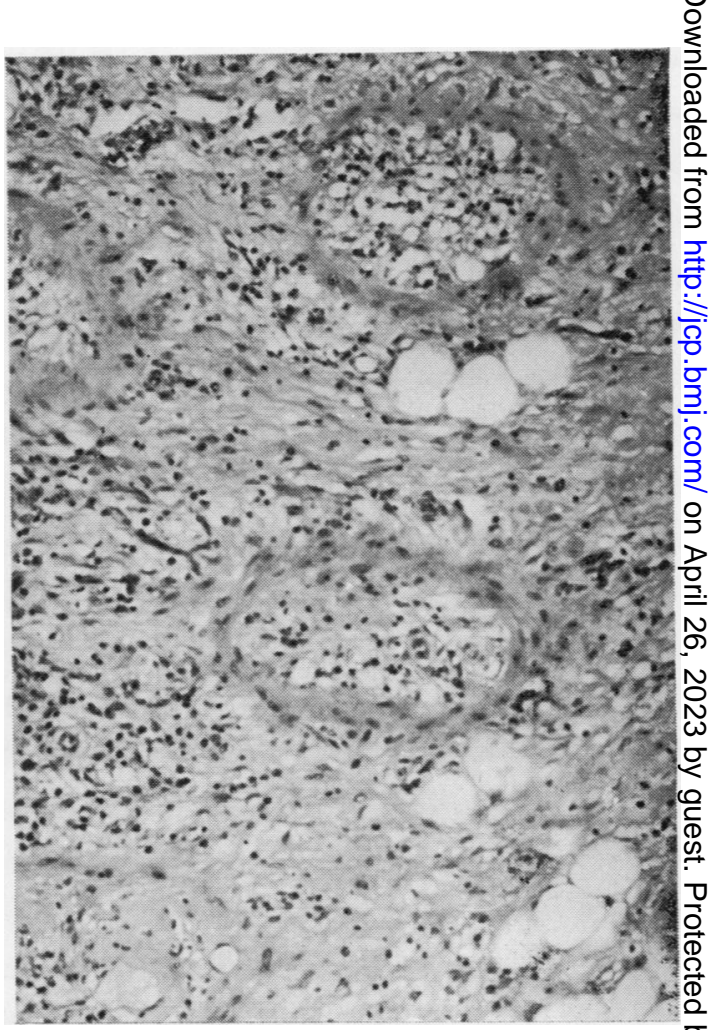

থ

Fig. 14 Four small occluded veins in spermatic cord. $\frac{8}{0}$ Interstitial and intraluminal lymphoid infiltrate.

Case 14: history 36 days. $H$ and $E \times 180$. 


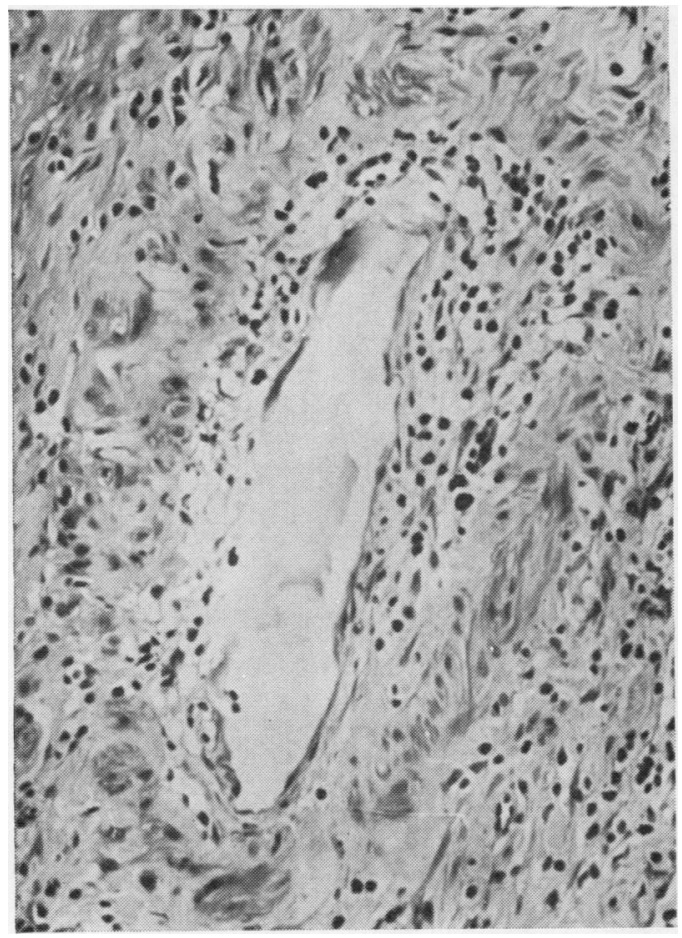

Fig. 15 Lymphoid intimal infiltrate of vein. Case 17: history 42 days. $H$ and $E \times 750$.

stained as lipofuscin of ceroid type, but in the epididymis some stained as haemosiderin.

The interstitium of the testes showed an intense infiltrate of plasma cells, lymphocytes, and histiocytes in those with a granulomatous response, but the areas of fibrotic tubules showed a minimal inflammatory infiltrate. No interstitial Leydig cells were identified in any specimen. Giant cells were exceedingly rare within granulomatous tubules, being seen in only two cases, but a central collection of polymorphs was commonly present within the lumen of the granulomatous tubules (Fig. 8).

No spermatozoa were seen in any specimen. Despite inflammation of the epididymis in all cases, with destruction of some tubules and aggregates of polymorphs and lipid-laden histiocytes, extravasated spermatozoa or sperm heads were not seen.

\section{Discussion}

These lesions bear close similarities between each other and show a mixture of infarction and infection of the testes. The appearances are, in many respects, reminiscent of renal papillary necrosis in so far as in each tubules undergo

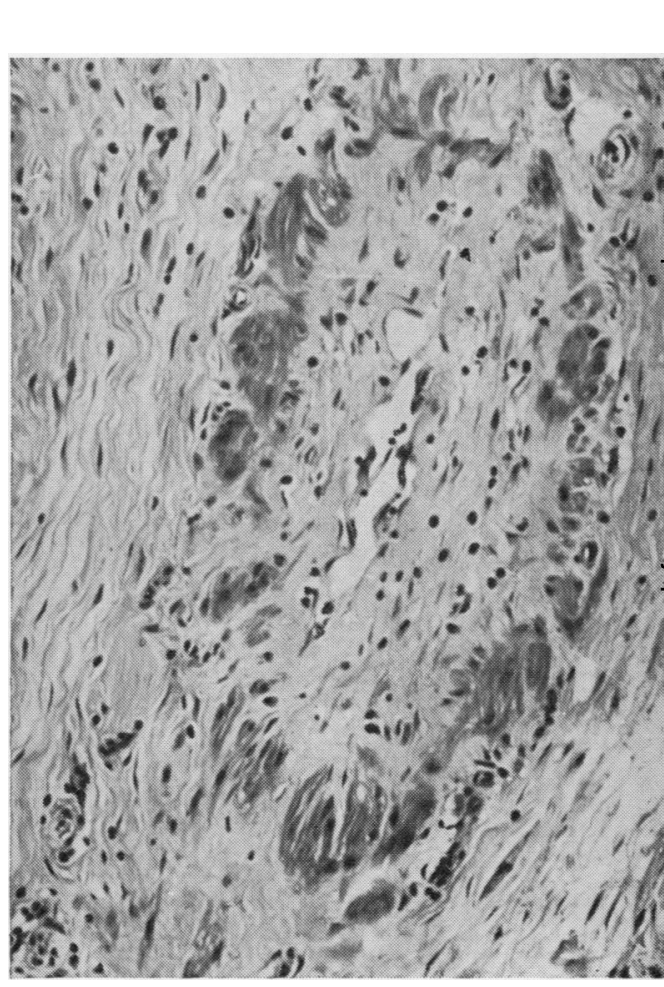

Fig. 16 Severe intimal fibrosis of vein.

Case 17: history 42 days. $H$ and $E \times 750$.

necrosis and are infiltrated by polymorphs ando yet tubular outlines remain.

The clinical histories and presentation suggest $2 \vec{p}$ banal infection of the bladder which subsequently spreads to the epididymis. The tunica breaks down and allows the formation of a discharging. scrotal sinus. There is no fundamental differences between patients with granulomatous and nongranulomatous lesions, and in four instances. transitions between fibrotic and granulomatous tubules could be seen, supporting the suggestion that granulomatous orchitis results from a chronico pyogenic infection (Lynch, Eakins, and Morrison, 1968).

The role of the venous occlusions is of grea interest; the fact that most were organized or in the process of organization means that they weres about four to six weeks old. They may have्w occurred as thrombi at the time of the initiab epididymoorchitis, either as a result of suppura tive involvement or of venous stagnation, and lec to an area of venous infarction which subsequent $\frac{?}{4}$ ly became infected, or they may have been manyo years old, following previous infections or the trauma of surgery (ipsilateral hernial repair in three cases). There is little evidence in favour of suppurative destruction of vein walls as in onlyo one case was there circumstantial support for this in the form of scarring of the medial coat, and the presence of inflammatory cells within most of the 
venous occlusions suggests that they were not very old, a conclusion supported by the absence of organized pink-staining collagen with van Gieson stain. The presence of necrotic tubules with an inflammatory or haemorrhagic reaction at the edge of the zone of necrosis would also suggest that these lesions were weeks rather than years old.

Thrombosis during the course of epididymoorchitis would seem to be the most likely explanation for these vascular lesions, as the interval of three to nine weeks between onset and orchidectomy would allow time for organization to take place. Although the turgid friable organ of venous infarction was not found it is reasonable to suggest that the engorgement with blood had been cleared by cellular activity before the orchidectomy.

Ischaemia has been proposed as the cause of granulomatous orchitis (Dreyfuss, 1956), and many published series include cases with large areas of testicular necrosis similar to those described here (Spjut and Thorpe, 1954; Lynch et al, 1968). Since 1964 we have seen two cases of granulomatous orchitis in which necrotic areas were not evident, but these have not shown venous occlusions and it would appear that vascular obstruction is related more to the development of testicular necrosis rather than to the granulomatous inflammatory reaction.

The grouping of granulomatous and nongranulomatous testes allowed comparisons between the two, and it became clear after histological study that transitions between the two were common and might be seen in a single testis. These findings support the idea of pyogenic infection rather than an immune mechanism as the cause of this unusual histological reaction.

The history of previous repair of an ipsilateral inguinal hernia is of interest, as the possibility of venous injury at this time must be considered. The data on the remaining patients may be inadequate, but it would seem unwise to ascribe aetiological significance to the earlier surgery.

The absence of normal spermatogenesis in the surviving tubules probably reflects a general sup $\frac{\rho}{5}$ pression as a result of the local inflammation, and is responsible for the absence of extravasated spermatozoa around the inflamed epididyma $\stackrel{p}{.}$ tubules. This, together with the absence of meta $\vec{F}$ plastic epithelium and the indistinctly granulo $\frac{?}{?}$ matous nature of the epididymal inflammation? contrasts with the findings in patients with spermatic granuloma (Glassy and Mostofi, 1956).

The presence of lipid and lipofuscin pigment of ceroid type within cells in granulomatous orchitisen and spermatic granuloma has led Phillips (1961) to postulate that spermatozoa have given rise to each of these inflammatory reactions. Similar $\vec{\omega}$ findings were present in some of the cases pres? sented here, but the evidence for a pyogeniog infection seems very strong, and it would appeari more likely that the lipid and pigment haveo resulted secondarily from necrotic cells.

From this study it seems reasonable to conclude that when an abscess develops in the testis of a patient with epididymoorchitis this is associated with multiple occlusions of veins within the epi-z didymis and spermatic cord, and a causal relationship probably exists between the abscess and the vascular lesions. The abscess usually has the histology of an infected infarct, and is generally situated at the antihilar border of the gonad.

My thanks are due to Mr F. Murray for meticu产 lous care with the photographs, and to Miss $\mathrm{J} . \frac{\mathscr{Q}}{\mathbb{D}}$ Fowler for secretarial assistance.

\section{References}

Dreyfuss, W. (1954). Acute granulomatous orchitis. J. Urot (Baltimore), 7, 483-487.

Glassy, F. J., and Mostofi, F. K. (1956). Spermatic granuloma of the epididymis. Amer. J. clin. Path., 26,1303-1313.

Lynch, V. P., Eakins, D., and Morrison, E. (1968). Granulomatous. orchitis. Brit. J. Urol., 40, 451-458.

Phillips, D. E. (1961). Lipid granuloma of the testis and epididymis. Brit. J. Urol., 33, 448-452.

Spjut. H. J., and Thorpe, J. D. (1956). Granulomatous orchitis? Amer. J. clin. Path., 26, 136-145. 